\title{
Kainari, a Unique Greek Traditional Herbal Tea, from the Island of Lesvos: Chemical Analysis and Antioxidant and Antimicrobial Properties
}

\author{
Evangelia Bampali, Konstantia Graikou, Nektarios Aligiannis, and Ioanna Chinou \\ Department of Pharmacognosy and Chemistry of Natural Products, Faculty of Pharmacy, School of Health Sciences, \\ National and Kapodistrian University of Athens, Panepistimiopolis-Zografou, 15771 Athens, Greece \\ Correspondence should be addressed to Ioanna Chinou; ichinou@pharm.uoa.gr
}

Received 1 September 2017; Accepted 16 November 2017; Published 26 February 2018

Academic Editor: Yoshiji Ohta

Copyright (c) 2018 Evangelia Bampali et al. This is an open access article distributed under the Creative Commons Attribution License, which permits unrestricted use, distribution, and reproduction in any medium, provided the original work is properly cited.

\begin{abstract}
The chemical composition, as well as the total phenolic content (TPC) and the potential antioxidant and antimicrobial activity, of three Kainari-herbal tea samples from different areas of Lesvos Island (Greece) was evaluated. The rich aroma of the mixtures was studied through GC-MS, as well as through Headspace Solid-Phase Microextraction (HS-SPME)/GC-MS analyses. Cinnamon, clove, nutmeg, pepper, and ginger were identified as main ingredients, while, throughout the chemical analysis of the volatiles of one selected sample, several secondary metabolites have been isolated and identified on the basis of GC-MS as well as spectral evidence as eugenol, cinnamic aldehyde and myristicin, cinnamyl alcohol, alpha-terpinyl acetate, and $\beta$-caryophyllene. Furthermore, two food dyes, azorubine and amaranth, were also isolated and identified from the infusions. The total phenolic content was estimated and the free radical scavenging activity was determined by DPPH and ABTS assays and the antimicrobial activity of the extracts was tested showing a very interesting profile against all the assayed microorganisms. Due to its very pleasant aroma and taste properties as well as to its bioactivities, Kainari-herbal tea could be further proposed as functional beverage.
\end{abstract}

\section{Introduction}

For over thousand years, herbs and plants have played a major role in traditional and herbal based medicines. Herbal infusions and plants are the major source of phenolic compounds in our diet. It is known that phenolic compounds have many biological activities such as antioxidant and antimicrobial [1]. Due to the increasing popularity of a whole market for herbal dietary supplements and traditional medicines, we present in this study the chemical analysis and potential bioactivities of a unique herbal tea combination named "Kainari."

Kainari is a combination (mixture) of several spices, in powder form, which is used as herbal tea, usually with an intense red color, traditionally prepared in the Greek island of Lesvos and used in folk medicine as a warming beverage in winter. Historically, it was brought to the island from Greek emigrants from Asia Minor in early 19th century. In Turkey, a similar herbal tea called "kaynar" (means in Turkish boiled) or Lohusa Serbeti (convalescence serbet) is used traditionally in childbirth to give energy to the new mothers and to boost their lactation [2].

The tradition of making "Lohusa Serbeti" after a birth probably is derived from Byzantine birth tradition (custom) where what was called "lochozema," a nourishing broth, was given to new mothers $[2,3]$. It is mentioned in ceremonial books that after the birth of an imperial child "Porphyrogenitus" and in one-week-long period of celebration, the preparation of "lochozema," a nutritious "childbed soup like" broth, was offered in Constantinople's main streets. Then, as birth custom, it was given to all new mothers, to aid milk production and recovery $[4,5]$.

The exact history of "Lohusa Serbeti" is not known but the drink was certainly popular during the latter part of the Ottoman Empire (1299-1922), when the drink was given to new mothers, people that visited the new mother and with jugs of the drink also sent to the mother's friends, family, and cleric as a way of announcing the birth of her child. After drinking "Lohusa Serbeti" everybody present had to say a 
prayer asking God to bless the new mother with a plentiful supply of breast milk [2]. A fifteenth-century Turkish poem by Suleyman Celebi describes how Amine, mother of the prophet Muhammed, is given serbet to quench her thirst during labour [6].

It is also important the red color of the drink as it is a symbol in Turkey for good luck and joy [2], but also has a symbolic imperial importance [7]. Moreover, red color is considered apotropaic, by which is meant that red color is thought to ward off evil so by giving a red drink to a new lactating mother, protect both the mother and her baby [2].

To prepare "Lohusa Serbeti," water, cinnamon sticks and cloves, and "lohusa" sugar (pink-red in color, natural red color, or red food dye) are boiled together, to be served hot in winter or cold during summer $[2,8,9]$.

"Kainari," as already referred to, arrived to Lesvos Island after 1922 and it is used as a pleasant, aromatic, tonic, warming beverage. The composition of the mixture differentiates from "Lohusa Serbeti" and in our days, Kainari infusion is prepared by adding hot water to half spoon of Kainari mixture, which is produced by mixing powders of several spices, while the exact composition of mixture is kept secret. Some of the ingredients that are usually part of the herbal tea combination are mainly cinnamon and clove and in smaller quantities other spices such as ginger, nutmeg, galangal, and pepper.

The objective of this research was to study, for the first time, to the best of our knowledge, the composition of three different Kainari samples from three villages of Lesvos Island (Greece), as well as to evaluate the total phenolic content (TPC) and the potential antioxidant and antimicrobial activity. Six volatile compounds and two azo food dyes have been isolated and identified. The total phenolic content was estimated by Folin-Ciocalteu method and the free radical scavenging activity was determined by DPPH and ABTS assays. Moreover, the antimicrobial activity of the samples was tested against six Gram-positive and Gram-negative bacteria, two oral pathogens, and three pathogenic fungi.

\section{Materials and Methods}

2.1. Materials. Three samples of Kainari were obtained from different areas of Lesvos Island: Mytilene (KN1), Paleochori (KN2), and Agiassos (KN3). Analytical grade solvents (pentane, methanol, and water) were used for the extractions and the chromatographic techniques. The chemicals used throughout this study such as 1,1-diphenyl-2-picrylhydrazyl (DPPH), 2,2azino-bis-(3-ethylbenzothiazoline-6-sulfonic acid) (ABTS), Folin-Ciocalteu reagent, gallic acid, caffeic acid and Trolox powder, silica RP-18, and silica gel plates (Kieselgel 60 F254 $20 \times 20 \mathrm{~cm}$ ) were purchased from Sigma-Aldrich and Merck.

\subsection{Methods}

\subsubsection{Preparation of Extracts}

(i) Preparation of Herbal Teas (KN1 Aq, KN2 Aq, and KN3 $A q$ ). $0.4500 \mathrm{~g}$ of each of the Kainari samples was extracted using $200 \mathrm{~mL}$ of boiled distilled water left for $45 \mathrm{~min}$ at $25^{\circ} \mathrm{C}$. The filtrates were freeze-dried (Alpha I5, Christ, Osterode am Harz, Germany) and stored in desiccator. (ii) Preparation of Methanol Extracts (KN1 Meth, KN2 Meth, and KN3 Meth). $0.9750 \mathrm{~g}$ of each of the Kainari samples was extracted using $400 \mathrm{~mL}$ of methanol for 2 hours at $25^{\circ} \mathrm{C}$ and after filtration was evaporated in a rotary evaporator (R-200, Büchi, Flawil, Switzerland) and stored at $-20^{\circ} \mathrm{C}$ until further analysis.

(iii) Preparation of Pentane Extracts. $0.4500 \mathrm{~g}$ of each of the Kainari samples was extracted using $200 \mathrm{~mL}$ of pentane for 2 hours at $25^{\circ} \mathrm{C}$ and after filtration was evaporated (R-200, Büchi, Flawil, Switzerland) and stored as previously.

\subsubsection{Isolation of Compounds}

(i) Isolation of Volatile Compounds. The essential oil of sample KN2 was received by Clevenger distillation using $15.00 \mathrm{~g}$ of sample KN2. The distillate A (35 mL), consisting of essential oil and aromatic water, was collected in a flask, while $2 \mathrm{ml}$ of pure essential oil B was collected separately and analyzed through GC-MS.

In the distillate $\mathrm{A}$ was added $2 \mathrm{~g}$ of $\mathrm{NaCl}$ and the solution was cooled in ice water and transferred to a separatory funnel with $50 \mathrm{~mL}$ of hexane. The aqueous layer A1 was discarded, and the organic layer A2 was evaporated via rotary evaporation (R-200, Büchi, Flawil, Switzerland) to yield an oily extract C. In the extract C $15 \mathrm{~mL}$ hexane and $25 \mathrm{~mL}$ of $5 \% \mathrm{NaOH}$ were added for further liquid-liquid separation. The aqueous layer $\mathrm{Cl}$ contained the sodium salt of eugenol, while the eugenol acetate, $\beta$-caryophyllene, myristicin, and cinnamic aldehyde remained in the organic layer $\mathrm{C} 2$.

Layer $\mathrm{C} 1$ was then evaporated and cooled on ice, while $50 \mathrm{~mL}$ of $6 \mathrm{M} \mathrm{HCl}$ was added to the solution, ensuring that the solution was acidic and it was extracted with $15 \mathrm{~mL}$ hexane yielding eugenol, which was identified through NMR, GCMS, and comparison with literature data [10].

The organic layer C2 was chromatographed through preparative thin layer chromatography on silica gel plates using cyclohexane/dichloromethane $30 / 70 \mathrm{v} / \mathrm{v}$ as mobile phase, yielding cinnamic aldehyde, myristicin, cinnamyl alcohol, alpha-terpinyl acetate, and $\beta$-caryophyllene. All compounds were identified through NMR and/or GC-MS and literature data $[11,12]$.

(ii) Isolation of Azo Dyes. The freeze-dried herbal teas of $\mathrm{KN} 1$ and KN2 (454 mg), which presented the same chromatographic profile, and the freeze-dried herbal tea of KN3 (450 mg) were separately further purified using a medium pressure liquid chromatography MPLC (Borosilikat 3.3 Code Number 28147, Büchi, Flawil, Switzerland) packed with reversed phase silica gel (RP18) and two Series 1 pumps with flow speed $8 \mathrm{~mL} / \mathrm{min}$, eluted with decreasing polarities: $\mathrm{H}_{2} \mathrm{O} / \mathrm{MeOH}$ (100/0 to $\left.0 / 100\right)$. Azorubine was isolated and identified from the water fraction of KN1-KN2 and amaranth from KN3. The isolated compounds were identified by NMR and literature data [13].

\subsubsection{Identification of Compounds}

(i) Headspace Solid-Phase Microextraction (HS-SPME). The rich aroma of the Kainari samples was studied through HSSPME/GC-MS analyses [14]. The HS-SPME was performed with carboxen/polydimethylsiloxane coated fiber $(75 \mu \mathrm{m}$ coating 57330-U, Supelco, Bellefonte, PA, USA) attached in 
a manual SPME fiber holder (Supelco). For SPME extraction, $10 \mathrm{mg}$ of each sample in a glass vial $(15 \mathrm{~mL})$ closed with PTFE coated silicone rubber septum was used. The temperature in our experiment was set at $70-75^{\circ} \mathrm{C}$ and the vial with sample was placed on the hot-plate for 15 minutes. After that time, the fiber was exposed for 5 minutes and then it was transferred to perform GC-MS analysis.

(ii) GC-MS Analysis. The analyses were performed on a HP 6890 GC with 5973 MSD (Hewlett-Packard, Germany), with ionization energy $70 \mathrm{eV}$. The $\mathrm{GC}$ is equipped with a 1/10 split/splitless injector and a $30 \mathrm{~m}$ long DP5 capillary column, $0.25 \mathrm{~mm}$ internal diameter, and $0.25 \mathrm{~mm}$ thickness. The temperature in the injection sample was $200^{\circ} \mathrm{C}$ and gas was $\mathrm{He}$ and flow rate is $0.7 \mathrm{~mL} / \mathrm{min}$. Identification was made using the Wiley275 library and bibliographic data. The temperature programs that have been used are the following:

Temperature Program I. The initial temperature is $100^{\circ} \mathrm{C}$ and then rises at a rate of $4^{\circ} \mathrm{C} / \mathrm{min}$, up to a maximum temperature of $300^{\circ} \mathrm{C}$. Total analysis time was $52 \mathrm{~min}$. This program was used to analyze methanol and pentane extracts.

Temperature Program II. The initial column temperature is $50^{\circ} \mathrm{C}$ which is maintained for 3 minutes and then increased at a rate of $30^{\circ} \mathrm{C} / \mathrm{min}$ to $150^{\circ} \mathrm{C}$. From $150^{\circ} \mathrm{C}$, it rises at a rate of $3^{\circ} \mathrm{C} / \mathrm{min}$ up to $250^{\circ} \mathrm{C}$, where it remains for $10 \mathrm{~min}$. It was used for the HS-SPME analyses [10].

Temperature Program III. The initial column temperature is $60^{\circ} \mathrm{C}$ and then increases at a rate of $3^{\circ} \mathrm{C} / \mathrm{min}$ to a maximum temperature of $280^{\circ} \mathrm{C}$. Total analysis time was $93 \mathrm{~min}$. It was used for the analysis of the essential oil B.

(iii) Nuclear Magnetic Resonance (NMR). ${ }^{1} \mathrm{H}-\mathrm{NMR}$ spectra were obtained on a Bruker DRX 400 instrument $(400 \mathrm{MHz})$ using $\mathrm{CD}_{3} \mathrm{OD}, \mathrm{CDCl}_{3}$, and DMSO-d6 as solvents and TMS as an internal standard.

\subsubsection{Antioxidant Properties}

(i) Total Phenolic Content (TPC). It was determined by using Folin-Ciocalteu method with slight modifications [15]. As referred to literature, $10 \mathrm{mg}$ of each crude methanol extract or lyophilized herbal tea was dissolved in $1 \mathrm{~mL}$ of corresponding extracting solvent to produce the stock of sample solution. The lower concentrations of sample were prepared by diluting $100 \mu \mathrm{L}$ of the stock sample solution with $900 \mu \mathrm{L}$ methanol or distilled water. Then, $50 \mu \mathrm{L}$ of sample was put in a test tube and mixed with $60 \mu \mathrm{L}$ of Folin-Ciocalteu reagent, followed by an addition of $120 \mu \mathrm{L}$ of $35 \%$ sodium carbonate after 3 minutes. Then, the resulting mixture was incubated in dark at room temperature for an hour and absorbance was measured at $725 \mathrm{~nm}$ (UV-1700, Shimadzu Corporation, Kyoto, Japan) after incubation. Caffeic acid was used as calibrated standard and results were expressed as milligram Caffeic Acid Equivalent per gram of dry extract (mg CAE/g dry extract). The content of phenolics for each extract was determined in triplicate.

Alongside, $25 \mu \mathrm{L}$ of extracts or standard solution of gallic acid $(2.5$ to $100 \mu \mathrm{g} / \mathrm{mL})$ in DMSO was added to $125 \mu \mathrm{L}$ of a Folin-Ciocalteu solution $(10 \% \mathrm{v} / \mathrm{v})$, followed by $100 \mu \mathrm{L}$ of sodium carbonate $(7.5 \% \mathrm{w} / \mathrm{v})$ in a 96 -well plate. The reagents were mixed and incubated for 30 minutes at room temperature protected from light and the absorbance was measured at $765 \mathrm{~nm}$. Total phenolic content was expressed as mg Gallic Acid Equivalents per gram of dry extract (mg GAE/g dry extract). The content of phenolics for each extract was determined in triplicate.

(ii) 1,1-Diphenyl-2-picrylhydrazyl (DPPH) Assay. The DPPH radical scavenging assay was performed according to a previously described method [15]. The stock DPPH solution $(314 \mu \mathrm{M})$ was prepared in absolute ethanol and kept in dark at room temperature until its use. Gallic acid was used as a positive control (IC50: $4.5 \mu \mathrm{g} / \mathrm{mL}$ ) and the total extracts were diluted in DMSO at appropriate concentrations. Briefly, in a 96 -well plate, $190 \mu \mathrm{L}$ of the DPPH solution and $10 \mu \mathrm{L}$ of gallic acid or samples were incubated for $30 \mathrm{~min}$ at room temperature protected from light and the absorbance was measured at $517 \mathrm{~nm}$. A negative control containing $10 \mu \mathrm{L}$ DMSO and $190 \mu \mathrm{L}$ DPPH was performed each time, as well as blanks containing $10 \mu \mathrm{L}$ sample and $190 \mu \mathrm{L} \mathrm{EtOH}$.

(iii) 2,2-Azino-bis-(3-ethylbenzothiazoline-6-sulfonic Acid) (ABTS) Assay. The ABTS radical cation scavenging assay was performed using the method reported by Re et al. (1999) with slight modifications [16]. In brief, a stock ABTS aqua solution $(7 \mathrm{mM})$ was reacted with potassium persulfate aqua solution ( $2.45 \mathrm{mM})$ and kept overnight in dark to yield a dark colored solution containing $\mathrm{ABTS}^{\circ+}$ radical cation. Trolox was used as a positive control (IC50: $8.3 \mu \mathrm{g} / \mathrm{mL}$ ) and the total extracts were diluted in DMSO at appropriate concentrations. Prior to use in the assay, the $\mathrm{ABTS}^{-+}$radical cation was diluted with distilled water for an initial absorbance of about 0.700 $( \pm 0.02)$ at $734 \mathrm{~nm}$. Afterwards, in a 96 -well plate $100 \mu \mathrm{l}$ of $\mathrm{ABTS}^{\circ+}$ radical cation solution and $50 \mu \mathrm{l}$ of Trolox or samples were added, incubated for $10 \mathrm{~min}$ at room temperature, and protected from light and the absorbance was measured at $734 \mathrm{~nm}$. A negative control containing $50 \mu \mathrm{L}$ DMSO and $100 \mu \mathrm{L}$ ABTS was performed each time, as well as blanks containing $50 \mu \mathrm{L}$ sample and $100 \mu \mathrm{L}$ dist. $\mathrm{H}_{2} \mathrm{O}$.

The percentage of $\mathrm{DPPH}$ and ABTS scavenging was estimated by the following equation:

$$
A A \%=\left\{\frac{[(A-B)-(C-D)]}{(A-B)}\right\} \times 100 .
$$

$A$ is the control (without sample), $B$ is the blank (without sample, without DPPH/ABTS), Cis the sample, and $D$ is the blank sample (without DPPH/ABTS). IC50 values were estimated for the most active extracts.

For both experiments which referred to the free radical scavenging, all samples were analyzed in triplicate. Measurements were performed using a TECAN Infinite M200 PRO multimode reader (Tecan Group, Männedorf, Switzerland).

2.2.5. Antimicrobial Bioassay. The methanol extracts and the herbal teas of Kainari were evaluated for their in vitro antimicrobial activities using the standard antibiotics netilmicin, amoxicillin, and clavulanic acid in order to evaluate the sensitivity of the tested bacteria, while 5-fluorocytosine and amphotericin were used as sensitivity controls of the 
TABLE 1: Comparative table for the powders of KN1, KN2, and KN3 with HS-SPME.

\begin{tabular}{lcccl}
\hline Compound & $\%$ area KN1 & $\%$ area KN2 & $\%$ area KN3 & Possible contained plant \\
\hline Cinnamic aldehyde & 9.88 & 10.00 & 15.19 & Cinnamomum cassia \\
Safrole & $<1 \%$ & $<1 \%$ & - & Myristica fragrans, Piper nigrum \\
Camphene & $<1 \%$ & 2.78 & - & Myristica fragrans, Piper nigrum \\
Eugenol & 34.50 & 30.18 & 22.71 & Syzygium aromaticum, Cinnamomum cassia, Myristica fragrans, Piper nigrum \\
$\alpha$-Copaene & 1.88 & 4.16 & 10.81 & Syzygium aromaticum, Piper nigrum \\
$\beta$-Caryophyllene & 15.61 & 30.18 & 33.16 & Cinnamomum cassia, Syzygium aromaticum, Piper nigrum Myristica fragrans, \\
$\alpha$-Humulene & 2.50 & 3.77 & 3.59 & Syzygium aromaticum, Piper nigrum, Elettaria cardamomum \\
Ar-Curcumene & 1.94 & 1.66 & - & Zingiber officinale \\
Zingiberene & 1.13 & 1.26 & - & Zingiber officinale \\
Myristicin & 3.34 & - & - & Myristica fragrans \\
\hline
\end{tabular}

tested fungi $[17,18]$. A total of eleven microorganisms were assayed among which there were four Gram-positive bacteria, Staphylococcus aureus (ATCC 25923), Staphylococcus epidermidis (ATCC 12228), Streptococcus mutans, and Streptococcus viridans, and four Gram-negative bacteria, Escherichia coli (ATCC 25922), Enterobacter cloacae (ATCC 13047), Klebsiella pneumoniae (ATCC 13883), and Pseudomonas aeruginosa (ATCC 227853), as well as three pathogen fungi Candida albicans (ATCC 10231), C. tropicalis (ATCC 13801), and C. glabrata (ATCC 28838).

\section{Results and Discussion}

3.1. Results from HS-SPME/GC-MS Analyses. All three samples of "Kainari" from Mytilini, Paleochori, and Agiassos in Lesvos were studied for the first time to our knowledge. The rich aroma of the mixture was studied through Headspace Solid-Phase Microextraction (HS-SPME)/GC-MS analyses. Furthermore, the pentane and methanol extracts were also studied through GC-MS with respective results. The major constituents that have been determined through GC-MS analyses were cinnamic aldehyde, eugenol, myristicin, $\beta$ caryophyllene, curcumene, and zingiberene, which can be related to the possible contained spices as shown in Table 1.

Through analyses of all extracts of the three samples (herbal teas, methanol, and pentane extracts) and the simultaneous use of bibliography we conclude that the main components in all three samples are cinnamon $(\sim 6 / 10)$ and clove $(\sim 3 / 10)$ and the remaining part $(1 / 10)$ corresponds to both nutmeg and ginger.

It is remarkable that, according to the analyses of the volatiles in $\mathrm{KN} 3$, they were not identified as the main components of ginger (Zingiber officinale) and consequently we assume that ginger is not included in the mixture or it is included in small quantities. As for the presence of cardamom and pepper, due to the lack of some of their main metabolites (some of them exist in other contained plants at the same time), we conclude that if they are present they will be in small quantities.

3.2. Isolation and Determination of Compounds. Six compounds were isolated from the essential oil of sample KN2 by applying a series of liquid-liquid extractions based on acidbase chemical reactions, as well as with preparative TLC: eugenol, cinnamic aldehyde, and myristicin were determined by NMR spectroscopy and GC-MS analysis, while cinnamyl
TABLE 2: Total phenolic content of the herbal teas of KN1, KN2, and KN3.

\begin{tabular}{lcc}
\hline & mg CAE/gr dry extract & mg GAE/gr dry extract \\
\hline Sample KN1 aq & 308.29 & 115.2 \\
Sample KN2 aq & 320.31 & 149.2 \\
Sample KN3 aq & 383.41 & 184.5 \\
\hline
\end{tabular}

TABLE 3: \% inhibition at DPPH and ABTS assay of herbal teas and methanol extracts.

\begin{tabular}{lcc}
\hline & DPPH & ABTS \\
& \% inhibition & \% inhibition \\
& $50 \mu \mathrm{g} / \mathrm{mL}$ & $10 \mu \mathrm{g} / \mathrm{mL}$ \\
\hline KN1 aq & $37.4 \pm 0.1$ & $28.4 \pm 0.1$ \\
KN2 aq & $50.2 \pm 1.4$ & $38.8 \pm 1.3$ \\
KN3 aq & $64.7 \pm 0.3$ & $46.9 \pm 0.9$ \\
KN1 meth & $64.6 \pm 0.3$ & $48.2 \pm 0.7$ \\
KN2 meth & $40.9 \pm 0.7$ & $26.9 \pm 0.7$ \\
KN3 meth & $61.4 \pm 0.1$ & $40.3 \pm 1.4$ \\
\hline
\end{tabular}

alcohol, alpha-terpinyl acetate, and $\beta$-caryophyllene were determined only by GC-MS analysis.

Also, two food dyes were isolated and identified as parts of the family of azo colors. Samples KN1 and KN2 contained the same food color azorubine [19], while sample KN3 contained amaranth [11].

The azo colors are compounds bearing the functional group $\mathrm{R}-\mathrm{N}=\mathrm{N}-\mathrm{R}^{\prime}$, where $\mathrm{R}$ and $\mathrm{R}^{\prime}$ may be either aryl or alkyl. Azo dyes are one of the most important chemical categories of dyes which are used for the coloring of natural and synthetic fibers, candies, and cosmetics but also food and beverages [20,21]. Many azo dyes are nontoxic, although some of them have been accused for allergic reactions and increasing hyperactivity in children [22].

The two isolated compounds are being referred to EFSA as amaranth (E123) and azorubine or carmoisine (E122) and are well-known food dyes [19, 23].

3.3. Antioxidant Properties. The total phenolic content (TPC) of the three samples was notably high, probably due to the known rich phenolic concentration of all spices that they contain $[24,25]$. The sample KN3 revealed the higher concentration of phenolic content (Table 2).

The free radical scavenging activities of herbal teas and methanol extracts were determined by DPPH and ABTS assays (Table 3). All extracts showed significant 


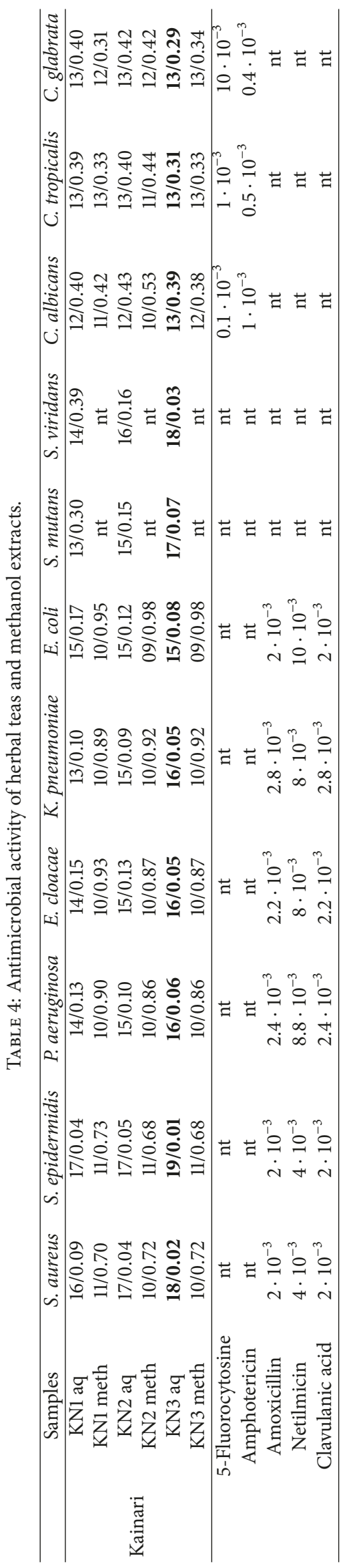


antioxidant activity performing 30-64\% inhibition at DPPH assay $(50 \mu \mathrm{g} / \mathrm{mL})$, as well as $26-48 \%$ inhibition at ABTS assay $(10 \mu \mathrm{g} / \mathrm{mL})$. The herbal tea $\mathrm{KN} 3$ performed the higher inhibition at DPPH (64.7\%) and at ABTS (46.9\%) which is in accordance with the high TPC. Also, the methanol extracts of KN1 and KN3 showed high inhibition.

3.4. Antimicrobial Bioassay. According to in vitro antimicrobial tests (Table 4) against two Gram-positive bacteria ( $S$. aureus and $S$. epidermidis) and four Gram-negative ones (E. coli, E. cloacae, K. pneumoniae, and P. aeruginosa), as well as against oral pathogens ( $S$. mutans and $S$. viridans) and three human pathogenic fungi (Candida albicans, C. tropicalis, and C. glabrata), the herbal teas exhibited a broad spectrum of strong antimicrobial activity, while KN3 herbal tea appeared to be the most active against all tested microorganisms, which can be explained by the high percentage of cinnamic aldehyde and $\beta$-caryophyllene that appears in herbal tea of KN3 as shown in Table 1.

\section{Conclusion}

In conclusion, the chemical composition, as well as the total phenolic content (TPC) and the potential antioxidant and antimicrobial activity, of three Kainari-herbal teas from different areas of Lesvos Island (Greece) was evaluated. All samples exerted very broad and strong antimicrobial activities against almost all Gram-positive and Gram-negative human pathogenic bacteria, as well as strong antioxidant activities.

According to the determined chemical analysis and total phenolic content, it could be concluded that "Kainari" herbal infusion, except its very pleasant taste, could be also further used as a functional herbal beverage, due to its beneficial properties, strong antioxidant, and antimicrobial activities for consumers. Certainly, more studies along the potential further bioactivities, as well as the entire process of the production of stable batches of "Kainari" combination at industrial level, have to be designed in future.

\section{Disclosure}

A preliminary version of this study, entitled "Kainari - A Greek Traditional Herbal Tea, from Lesvos Island. Chemical Analysis, Antioxidant and Antimicrobial Properties" by the same authors, has been subjected and accepted as poster presentation in ICNPU-2017, 3rd International Conference on Natural Products Utilization, which was held in Bansko, Bulgaria, 18-21 October 2017 (PP24).

\section{Conflicts of Interest}

The authors declare they have no conflicts of interest for this work.

\section{References}

[1] I. C. Arts and P. C. Hollman, "Polyphenols and disease risk in epidemiologic studies," American Journal of Clinical Nutrition, vol. 81, no. 1, pp. 317S-325S, 2005.
[2] V. Williams, Celebrating Life Customs around the World: From Baby Showers to Funerals [3 volumes], ABC-CLIO, 2016.

[3] A. Papaconstantinou and A-M. Maffry Talbot, Becoming Byzantine: children and childhood in Byzantium, vol. 1, Harvard University Press, 1, 2009.

[4] P. Koukoules, Speculum, vol. IV, П $\alpha \pi \alpha \zeta u \sigma \eta \varsigma, 1951$.

[5] G. Dagron, Emperor and priest: The imperial office in Byzantium, Cambridge University Press, 2003.

[6] O. A. Talât, Eski Türk Edebiyatında Mazmunlar ve İzahı, Akçağ Yayınları, Ankara, 2000.

[7] K. Albala, Food Cultures of the World Encyclopedia, Bloomsbury Publishing, 2011.

[8] Binnur's Turkish Cookbook, "Lohusa Şerbet," http://www.turkishcookbook.com/2010/03/lohusa-sherbet.php.

[9] "Lohusa Şerbeti: A Special Baby Sherbet." A Seasonal Cook in Turkey. June 15. 2011," http://seasonalcookinturkey.com/lohusaserbeti-special-baby-sherbet/.

[10] "Isolation of Eugenol, Organic Chemistry 241 Lab, Colby College".

[11] C. X. You, H. Y. Jiang, W. J. Zhang et al., "Contact toxicity and repellency of the main components from the essential oil of Clausena anisum-olens against two stored product insects," Journal of Insect Science, vol. 15, no. 1, 2015.

[12] Trans-Cinnamaldehyde, "HanHong. Web," http://www.hanhonggroup.com/nmr/nmr_en/B34317.html.

[13] E. M. Elgendy and N. A. Al-Zahrani, "Comparative Study of Natural and Synthetic Food Additive Dye Amaranth through Photochemical Reactions," Indian Journal of Science Research, vol. 4, pp. 827-832, 2015.

[14] K. G. Miller, C. F. Poole, and T. M. P. Pawlowskí, "Classification of the botanical origin of cinnamon by solid-phase microextraction and gas chromatography," Chromatographia, vol. 42, no. 1112, pp. 639-646, 1996.

[15] A. Bampouli, K. Kyriakopoulou, G. Papaefstathiou et al., "Evaluation of total antioxidant potential of Pistacia lentiscus var. chia leaves extracts using UHPLC-HRMS," Journal of Food Engineering, vol. 167, article no. 7970, pp. 25-31, 2015.

[16] R. Re, N. Pellegrini, A. Proteggente, A. Pannala, M. Yang, and C. Rice-Evans, "Antioxidant activity applying an improved ABTS radical cation decolorization assay," Free Radical Biology \& Medicine, vol. 26, no. 9-10, pp. 1231-1237, 1999.

[17] A. W. Bauer, W. M. Kirby, J. C. Sherris, and M. Turck, "Antibiotic susceptibility testing by a standardized single disk method," American Journal of Clinical Pathology, vol. 45, no. 4, pp. 493496, 1966.

[18] I. Wiegand, K. Hilpert, and R. E. W. Hancock, "Agar and broth dilution methods to determine the minimal inhibitory concentration (MIC) of antimicrobial substances," Nature Protocols, vol. 3, no. 2, pp. 163-175, 2008.

[19] "Scientific Opinion on the re-evaluation of Azorubine/Carmoisine (E 122) as a food additive," EFSA Journal, vol. 7, no. 11, p. 1332, 2009.

[20] R. L. M. Allen, Colour Chemistry, Thomas Nelson \& Sons, London, UK, 1979.

[21] K. Venkataraman, The Chemistry of Synthetic Dyes, Academic Press, London, UK, 1978.

[22] FDA, Background Document for the Food Advisory Committee: Certified Color Additives in Food and Possible Association with Attention Deficit Hyperactivity Disorder in Children, 2011.

[23] "Scientific Opinion on the re-evaluation of Amaranth (E 123) as a food additive," EFSA Journal, vol. 8, no. 7, p. 1649, 2010. 
[24] L. Su, J.-J. Yin, D. Charles, K. Zhou, J. Moore, and L. Yu, “Total phenolic contents, chelating capacities, and radical-scavenging properties of black peppercorn, nutmeg, rosehip, cinnamon and oregano leaf," Food Chemistry, vol. 100, no. 3, pp. 990-997, 2007.

[25] D. F. Cortés-Rojas, C. R. F. de Souza, and W. P. Oliveira, "Clove (Syzygium aromaticum): A precious spice," Asian Pacific Journal of Tropical Biomedicine, vol. 4, no. 2, pp. 90-96, 2014. 


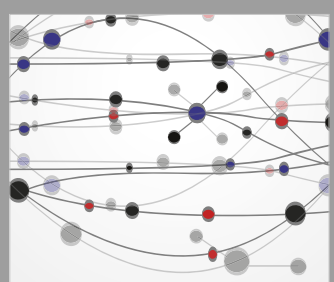

The Scientific World Journal
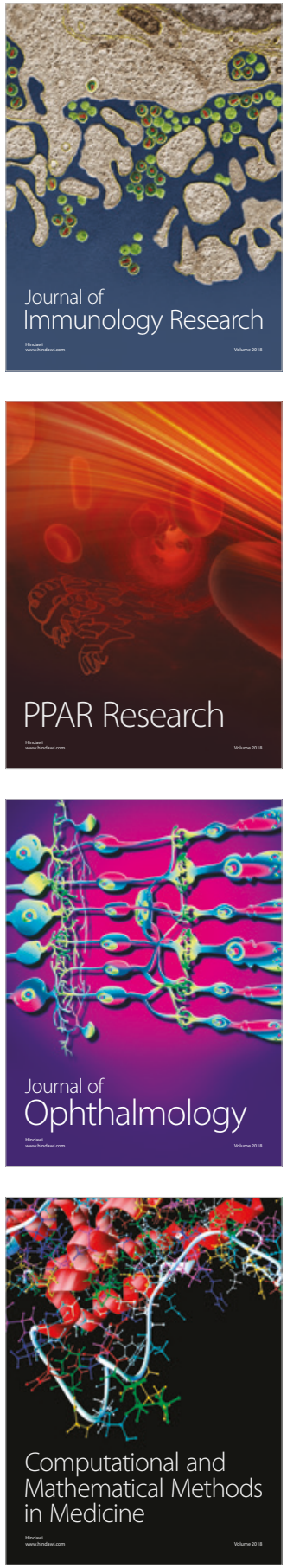

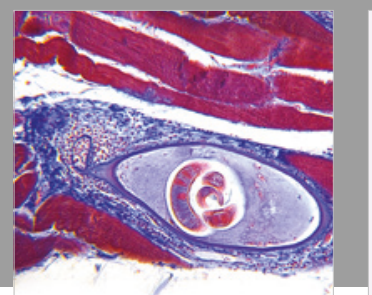

Gastroenterology Research and Practice

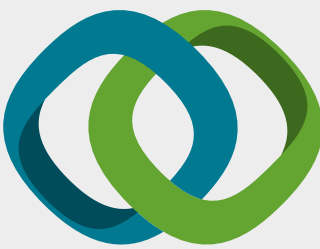

\section{Hindawi}

Submit your manuscripts at

www.hindawi.com
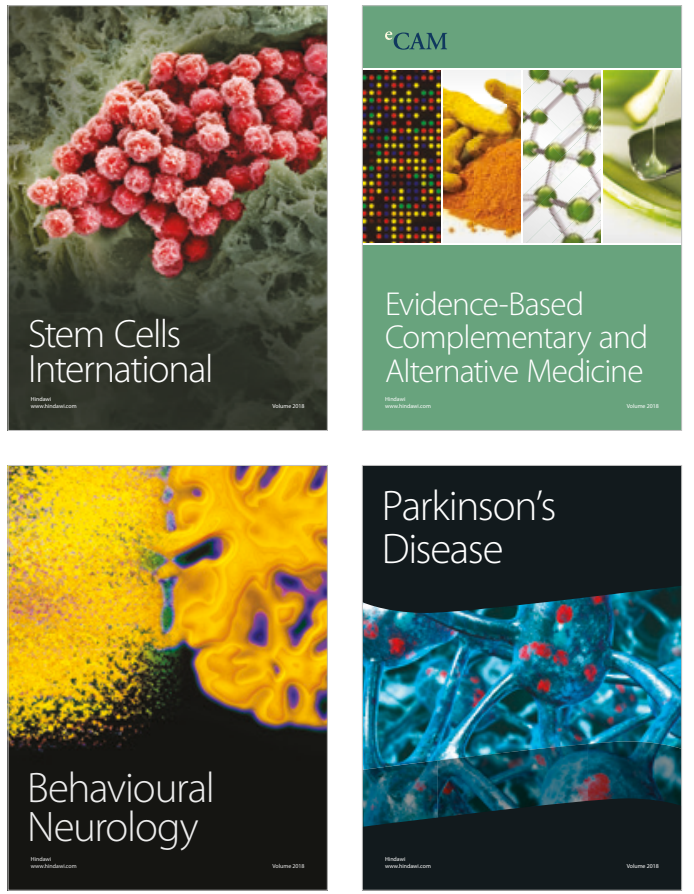

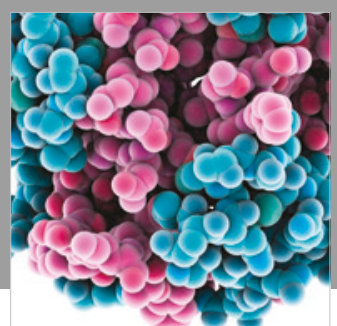

ournal of

Diabetes Research

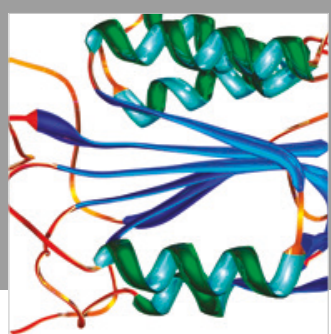

Disease Markers
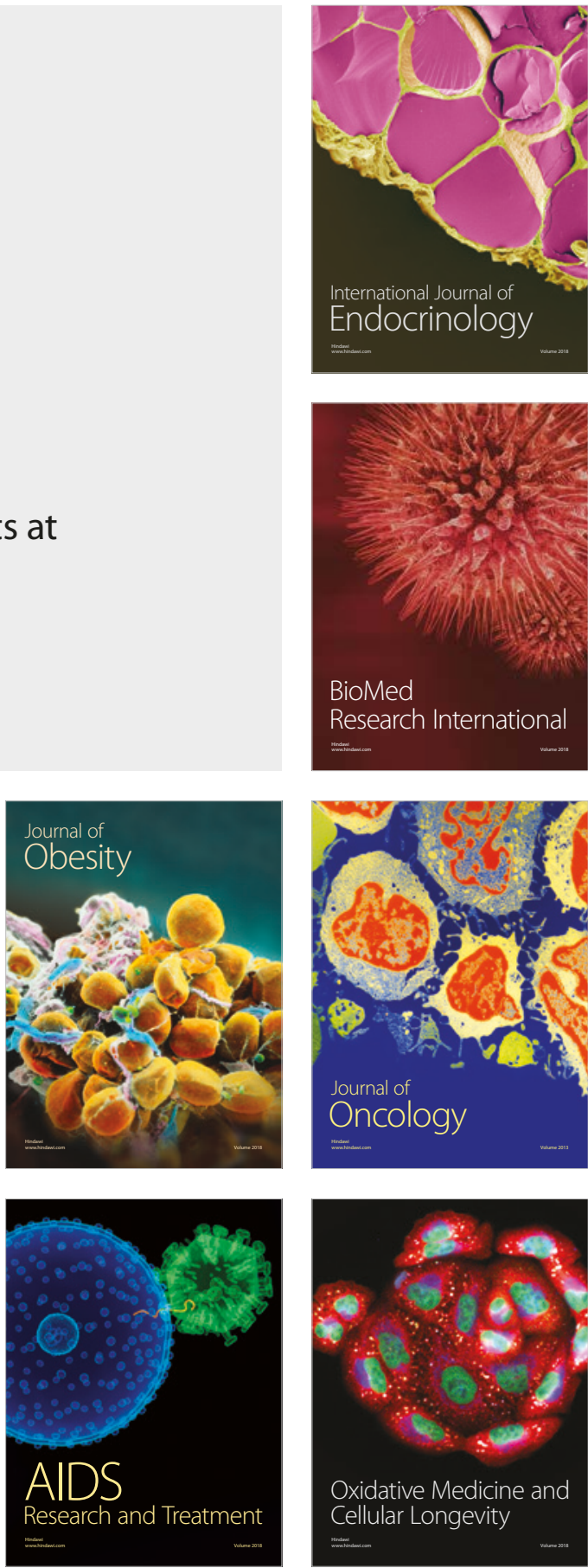